\title{
Multimineral Fortification of Chicken Egg by Supplementing a Combination of Sodium Selenite, Ferrous Sulphate and Zinc Sulphate in Layer Diet
}

\author{
Pushpamali RMD ${ }^{1}$, Himali SMC ${ }^{1 *}$, Gunawardene $\mathbf{M}^{2}$, Samarasinghe $\mathrm{K}^{1}$ and Chandrajith $\mathrm{R}^{3}$ \\ ${ }^{1}$ Department of Animal Science, Faculty of Agriculture, University of Peradeniya, Sri Lanka \\ ${ }^{2}$ Sri Lanka Institute of Nanotechnology, Mahenwatte, Pitipana, Homagama Sri Lanka
}

${ }^{3}$ Department of Geology, Faculty of Science, University of Peradeniya, Sri Lanka

*Corresponding author: Himali SMC, Department of Animal Science, Faculty of Agriculture, University of Peradeniya, Sri Lanka

\section{ARTICLE INFO}

Received: 幽April 15, 2021

Published: April 26, 2021

Citation: Pushpamali RMD, Himali SMC, Gunawardene M, Samarasinghe K, Chandrajith R. Multimineral Fortification of Chicken Egg by Supplementing a Combination of Sodium Selenite, Ferrous Sulphate and Zinc Sulphate in Layer Diet. Biomed J Sci \& Tech Res 35(2)-2021. BJSTR. MS.ID.005683.

Keywords: Selenium; Iron; Zinc; Laying Hen; Chicken Egg Fortification

\begin{abstract}
Since the bioavailability of organic minerals are highly effective in supplying minerals to the body, enriching of eggs with multiminerals could be an effective way to supply minerals to human beings. This study was conducted to investigate the effect of Sodium selenite $\left(\mathrm{Na}_{2} \mathrm{SeO}_{3}\right)$, Ferrous sulphate $\left(\mathrm{FeSO}_{4}\right)$ and $\mathrm{Zinc}$ sulphate $\left(\mathrm{ZnSO}_{4}\right)$ incorporated diet on Selenium (Se), Iron (Fe) and Zinc (Zn) concentrations of eggs, egg quality and productivity traits of layers. A feeding trial was conducted with Shaver Brown laying hens (65-week of age) for eight weeks. The dietary groups were basal diet and basal diet plus $\mathrm{Na}_{2} \mathrm{SeO}_{3}, \mathrm{FeSO}_{4}$ and $\mathrm{ZnSO}_{4}$ with the concentrations of Se $0.3 \mathrm{mg} / \mathrm{kg}$, Fe $120 \mathrm{mg} /$ $\mathrm{kg}$ and $\mathrm{Zn} 150 \mathrm{mg} / \mathrm{kg}$. Feed intake and egg production were recorded daily. The feed conversion ratio was calculated for the whole period. Concentrations of Se, Fe and $\mathrm{Zn}$ in egg samples were determined by using inductively coupled plasma mass spectrometer after microwave digestion in acidic media. Egg quality parameters including egg weight, shape index, eggshell strength, shell thickness, Haugh unit, yolk index, and yolk color were measured weekly and a sensory evaluation of hard boiled eggs was carried out at the end of the experimental period. Supplementation of mineral incorporated diet significantly increased Se and Zn concentrations in egg white by $28.6 \%$ and $50.9 \%$ $(\mathrm{P}<0.05)$ respectively. Fe concentration in egg yolk was increased by $15.7 \%(\mathrm{P}<0.05)$. Feed intake/hen/day, egg production/hen/week and feed conversion ratio/kg eggs were not significantly different among the treatment and control $(\mathrm{P}>0.05)$. Mineral supplemented diet markedly increased $(\mathrm{P}<0.05)$ egg weight and egg white weight than the control. The other egg quality characteristics showed a positive improvement, but with no statistically significant difference compared to the control group $(P>0.05)$. The results of sensory evaluation showed higher consumer preference to the yolk color $(\mathrm{P}>0.05)$ of mineral fortified eggs than the control. Mineral supplemented diet with $\mathrm{Na}_{2} \mathrm{SeO}_{3}(0.3 \mathrm{mg} / \mathrm{kg}), \mathrm{FeSO}_{4}(120 \mathrm{mg} / \mathrm{kg})$ and $\mathrm{ZnSO}_{4}(150 \mathrm{mg} / \mathrm{kg})$ can be recommended to fortification of eggs with Se, Fe and Zn successfully and, it results positive improvements in egg quality especially the yolk color. The egg production parameters are not affected by the fortification of mineral concentrations and combination used in the current study.
\end{abstract}

\section{Introduction}

Egg fortification with trace minerals is considered as a route towards the prevention of Micro Nutrient Malnutrition (MNM), which has increased greatly over the last few years (Food and Agriculture Organization/World Health Organization FAO/WHO [1]. MNM is one of the health problems widely found in both industrialized and developing countries in the world which contributes greatly to the global burden of diseases FAO/WHO [2]. MNM adversely affects all age groups, but risk of micronutrient deficiency is somewhat high 
among young children and women in reproductive age. According to the FAO/WHO report 2004, iodine, iron, vitamin A and zinc deficiencies are the world's most serious health risk factors FAO/ WHO [1]. Role of Se in human health and disease has been discussed in detail along with the deficiency problems in worldwide. As an essential trace element Se plays an important role in antioxidant selenoproteins for protection against oxidative stress originated by surplus reactive oxygen species and reactive nitrogen species in human body. A clear relationship has been observed between low levels of Se and increased risk of diseases, such as cancer and heart diseases Tinggi [3]. The low selenium concentration in the blood is associated with male subfertility Oguntibeju [4]. Recent studies on Se have been directed towards kidney protective efficiency of it. Randjelovic, et al. [5] have shown that the ability of selenium to reduce cardiovascular disease by reducing oxygen free radicals and lipid peroxidation. According to Wiesen, et al. [6] plasma selenium level has been decreased in patients with acute renal injury. But all over the world human populations in many countries are not provided with adequate level of selenium from their food WHO [7]. The level of selenium in human food varies among regions since the content of this element in plant-based food depends on its availability in soil Fisinin, et al. [8].

Iron is an integral part of many proteins that required for maintaining good health. In humans, iron serves as an essential component of proteins involved in oxygen transport Dallman [9]. It is vital for the regulation of cell growth and differentiation Andrews [10]. Iron deficiency limits oxygen delivery to cells, resulting in fatigue, poor work performances and decreased immunity Haas, et al. [11]. Iron is a part of haemoglobins and cytochromes and Zinc functions as essential accessory factor to enzymes Paul $[12,13]$. Around two billion people in the developing world are deficient with zinc Prasad [14]. It causes infections and diarrhoea which accounts for about 800,000 death per year among children worldwide Hambidge [15]. It is also responsible for the immune deficiency resulting susceptibility to infection especially in elderly population Meydani, et al. [16]. In poultry, Se increases egg production, fertility, antioxidant status, growth rate and reduces feather loss in young laying hens. It positively influences on storage capacity of eggs Edens [17]. Further, Se supplementation has shown to increase the settable eggs, fertility, hatch of fertile eggs, hatchability, and A-grade chicks and reduced embryonic mortality Khan, et al. [18].

Egg fortification is an effective way to deliver these important trace minerals to human body. It may be a good solution for the people who are at risk of trace mineral deficiency. In Sri Lanka chronic kidney disease of unknown etiology (CKDu) has become a significant burden health issue. In some districts the prevalence of CKDu is 15.1-22.9\% Rajapakse [19]. As deficiency of Se has a association, Se enriched egg consumption may have a significant effect on alleviation of this situation. However, in Sri Lanka fortified eggs are not common and the information on multimineral fortification in tropical climates are limited. In a successful mineral supplementation, the levels and combination of minerals used should not negatively affect to the egg production parameters and the quality of eggs while enriching eggs. Therefore, the objectives of this study were to investigate the effect of incorporation of combination of Sodium selenite, Ferrous sulphate and Zinc sulphate to layer diet on Se, Fe and Zn concentrations of eggs and to compare the quality characteristics of egg along with the hen's performance such as feed intake, feed conversion rate and egg production under tropical climatic conditions.

\section{Materials and Methods \\ Experimental Hens and Feeding Regimen}

The feeding trial was conducted at the Livestock Field Station, University of Peradeniya, Peradeniya, Sri Lanka. Shaver brown laying hens (65 weeks old), were randomly allocated into two groups as the treatment and the control. Each group consisted of three replicates of ten laying hens and they were reared according the deep litter system. Commercially manufactured layer ration was ground and used as the basal diet. For the preparation of experimental diet, the basal diet was mixed with $\mathrm{Na}_{2} \mathrm{SeO}_{3}, \mathrm{FeSO}_{4}$ and $\mathrm{ZnSO}_{4}$ at the concentrations of $0.3 \mathrm{mg} \mathrm{Se} / \mathrm{kg}$ diet, $120 \mathrm{mg} \mathrm{Fe} / \mathrm{kg}$ diet and $150 \mathrm{mg} \mathrm{Zn} / \mathrm{kg}$ diet respectively. Mineral concentrations were adjusted as reported by several authors Skrivan, et al. [16,20-23]. In commercial production of Se enriched eggs, $0.3 \mathrm{mg}$ of Se $/ \mathrm{kg}$ of feed is used Fisin, et al. [16]. Bahakaim, et al. [22] have recommended $150 \mathrm{mg}$ of $\mathrm{Zn} / \mathrm{kg}$ of feed for better enrichment of $\mathrm{Zn}$ in eggs. Skrivan, et al. [20] used $120 \mathrm{mg}$ of $\mathrm{Fe} / \mathrm{kg}$ with basal diet and found it could increase Fe concentration in egg significantly indicating the suitability of the level. The basal diet consists of $16.0 \%$ protein, $4.0 \%$ fat, $14.0 \%$ ash, $6.0 \%$ fiber, $3.0-4.0 \%$ Calcium, $0.70-1.0 \%$ Phosphorous and metabolizable energy $2630 \mathrm{kCal} / \mathrm{kg}$. The Se, Fe and $\mathrm{Zn}$ contents of the basal diet were $1.50 \pm 0.23,256.30 \pm 32$ and $20.33 \pm 0.88$ of $\mathrm{mg} / \mathrm{kg}$ respectively. Hens were supplied ad-libitum amount of feed and water. Every day the remaining amounts of feeds were measured and removed before introducing new feed. Temperature inside the cages was 27-30 $\circ \mathrm{C}$ and relative humidity was around $50-65 \%$. The experiment was conducted for 8 weeks including 2 weeks of acclimatization period.

\section{Productive Performances of Laying Hens}

Feed intake and egg production were recorded daily. Feed conversion rate was calculated as kilograms of feed consumed per kilogram of eggs.

\section{External Quality of Eggs}

Five eggs from each replicate were collected every week for analyses of egg weight, shape index, shell strength and shell thickness. Eggs were weighted individually, the width and the 
length of individual egg were measured. After breaking eggs, two halves of eggshell were wiped with tissue and kept upside down and allowed to remove albumen properly. Dried out shell was used to take the shell thickness. Shape index was calculated using the formulation (breadth/length x100) which described by Reddy, et al. [24].

\section{Internal Quality of Eggs}

The albumin weight, yolk weight, yolk index, Haugh unit, yolk color of five eggs from each replicate were used to determined weekly. Eggs were broken and yolk and albumin contents were separated and weights were recorded. Yolk height and albumin height were determined using a Haugh tester (ORKA digital Haugh tester, Lakeview Dr, Bountiful UT, USA). Yolk color was determined using Roche yolk color fan (ROCHE, Yolk color fan, Switzerland). Yolk index was obtained by the formulation described by Funk (1948). Individual Haugh unit was calculated using according to Haugh [25] (Table 1).

Table 1: Internal and external characteristics of eggs (Mean \pm Standard error, $n=15$ ).

\begin{tabular}{|c|c|c|c|c|c|c|c|c|c|c|c|c|}
\hline \multirow{2}{*}{ Parameter } & \multicolumn{2}{|c|}{$1^{\text {st }}$ week } & \multicolumn{2}{|c|}{$2^{\text {nd }}$ week } & \multicolumn{2}{|c|}{$3^{\text {rd }}$ week } & \multicolumn{2}{|c|}{$4^{\text {th }}$ week } & \multicolumn{2}{|c|}{$5^{\text {th }}$ week } & \multicolumn{2}{|c|}{$6^{\text {th }}$ week } \\
\hline & T1 & T2 & T1 & T2 & T1 & T2 & T1 & T2 & T1 & T2 & T1 & T2 \\
\hline Width (cm) & $\begin{array}{c}3.57 \pm \\
0.05^{\mathrm{a}}\end{array}$ & $\begin{array}{c}3.70 \pm \\
0.09^{\mathrm{a}}\end{array}$ & $\begin{array}{c}3.76 \pm \\
0.03^{\mathrm{b}}\end{array}$ & $\begin{array}{c}3.92 \pm \\
0.05^{\mathrm{a}}\end{array}$ & $\begin{array}{c}3.99 \pm \\
0.09^{\mathrm{a}}\end{array}$ & $\begin{array}{c}3.85 \pm \\
0.04^{\mathrm{a}}\end{array}$ & $\begin{array}{c}3.78 \pm \\
0.07^{\mathrm{b}}\end{array}$ & $\begin{array}{c}3.97 \pm \\
0.04^{\mathrm{a}}\end{array}$ & $\begin{array}{c}3.79 \pm \\
0.04^{\mathrm{a}}\end{array}$ & $\begin{array}{c}3.93 \pm \\
0.09^{\mathrm{a}}\end{array}$ & $\begin{array}{c}3.66 \pm \\
0.06^{\mathrm{a}}\end{array}$ & $\begin{array}{c}3.67 \pm \\
0.06^{\mathrm{a}}\end{array}$ \\
\hline Length $(\mathrm{cm})$ & $\begin{array}{c}5.81 \pm \\
0.16^{\mathrm{a}}\end{array}$ & $\begin{array}{l}5.66 \pm \\
0.15^{\mathrm{a}}\end{array}$ & $\begin{array}{c}5.70 \pm \\
0.15^{\mathrm{a}}\end{array}$ & $\begin{array}{l}5.91 \pm \\
0.03^{\mathrm{a}}\end{array}$ & $\begin{array}{c}5.84 \pm \\
0.04^{\mathrm{a}}\end{array}$ & $\begin{array}{c}5.79 \pm \\
0.04^{\mathrm{a}}\end{array}$ & $\begin{array}{l}5.91 \pm \\
0.08^{\mathrm{a}}\end{array}$ & $\begin{array}{c}5.87 \pm \\
0.07^{\mathrm{a}}\end{array}$ & $\begin{array}{c}5.90 \pm \\
0.05^{\mathrm{a}}\end{array}$ & $\begin{array}{c}5.83 \pm \\
0.05^{\mathrm{a}}\end{array}$ & $\begin{array}{c}6.07 \pm \\
0.09^{\mathrm{a}}\end{array}$ & $\begin{array}{c}5.76 \pm \\
0.06^{\mathrm{b}}\end{array}$ \\
\hline $\begin{array}{l}\text { Shell } \\
\text { thickness } \\
(\mathrm{cm})\end{array}$ & $\begin{array}{c}0.12 \pm \\
0.02^{\mathrm{a}}\end{array}$ & $\begin{array}{c}0.08 \pm \\
0.01^{\mathrm{b}}\end{array}$ & $\begin{array}{c}0.08 \pm \\
0.01^{\mathrm{a}}\end{array}$ & $\begin{array}{c}0.08 \pm \\
0.01^{\mathrm{a}}\end{array}$ & $\begin{array}{c}0.12 \pm \\
0.05^{\mathrm{a}}\end{array}$ & $\begin{array}{c}0.07 \pm \\
0.00^{\mathrm{a}}\end{array}$ & $\begin{array}{c}0.07 \pm \\
0.02^{\mathrm{a}}\end{array}$ & $\begin{array}{c}0.09 \pm \\
0.00^{\mathrm{a}}\end{array}$ & $\begin{array}{c}0.07 \pm \\
0.00^{\mathrm{a}}\end{array}$ & $\begin{array}{c}0.08 \pm \\
0.01^{\mathrm{a}}\end{array}$ & $\begin{array}{c}0.07 \pm \\
0.00^{\mathrm{a}}\end{array}$ & $\begin{array}{c}0.07 \pm \\
0.00^{\mathrm{a}}\end{array}$ \\
\hline $\begin{array}{c}\text { Shell } \\
\text { strength (N) }\end{array}$ & $\begin{array}{c}30.49 \pm \\
0.39^{\mathrm{a}}\end{array}$ & $\begin{array}{c}34.45 \pm \\
2.30^{\mathrm{a}}\end{array}$ & $\begin{array}{c}35.21 \pm \\
3.10^{\mathrm{a}}\end{array}$ & $\begin{array}{c}28.77 \pm \\
2.90^{\mathrm{a}}\end{array}$ & $\begin{array}{c}31.28 \pm \\
0.61^{\mathrm{a}}\end{array}$ & $\begin{array}{c}35.10 \pm \\
2.20^{\mathrm{a}}\end{array}$ & $\begin{array}{c}30.36 \pm \\
0.41^{\mathrm{a}}\end{array}$ & $\begin{array}{c}32.56 \pm \\
1.20^{\mathrm{a}}\end{array}$ & $\begin{array}{c}25.68 \pm \\
1.80^{\mathrm{b}}\end{array}$ & $\begin{array}{c}37.41 \pm \\
2.40^{\mathrm{a}}\end{array}$ & $\begin{array}{c}22.43 \pm \\
1.60^{\mathrm{b}}\end{array}$ & $\begin{array}{c}28.96 \pm \\
1.90^{\mathrm{a}}\end{array}$ \\
\hline
\end{tabular}

Note: $a, b$ Means with different superscripts within a raw in the same week differ significantly $(p<0.05)$.

\section{Evaluation of Se, Fe and Zn Content in Egg}

Eggs (six) from each group were sampled in third and sixth weeks for analysis of Se, Fe and Zn concentrations in egg yolk and egg albumin. Egg yolk and egg albumin were separated carefully and samples were properly homogenized separately using magnetic stirrer (P Selecta, Multimatic-5S, Barcelona, Spain). Egg yolk (0.50 g) and egg albumen (0.50 g) were weighted and each sample was digested in a mixture of $8 \mathrm{ml}, 69 \%$ Nitric acid $\left(\mathrm{HNO}_{3}\right)$ and $1 \mathrm{ml}$ of $35 \%$ Hydrogen peroxide $\left(\mathrm{H}_{2} \mathrm{O}_{2}\right)$ using a microwave digestion unit (MARS 6, CEM One TouchTM Technology, CEM GmbH, Germany). The digested samples were filtered and mineralisates were diluted with de-ionized water. Se, Fe and Zn of each sample were determined by inductively coupled plasma mass spectrometry (Model No. 7900, USA).

\section{Sensory Evaluation}

The yolk color, appearance, aroma, flavor and overall acceptability of two hard-boiled egg samples from two groups were evaluated in sensory evaluation with 30 untrained panelists using nine point hedonic scale system (1 - Dislike extremely, 9 like extremely). The sensory profiles were conducted on three digit-coded samples.

\section{Statistical Analyses}

The experimental design was Completely Randomized Design and data were analyzed using Minitab software package.
Differences at $\mathrm{P}<0.05$ were considered as significant. Sensory data were analyzed using Friedman non-parametric test using Minitab software package.

\section{Results}

\section{Productive Performances of Laying Hens}

The feed intake of the control and the treatment groups were $110.8 \pm 2.9$ and $110.2 \pm 3.8 \mathrm{~g} / \mathrm{hen} /$ day respectively and not significantly different $(\mathrm{P}>0.05)$. Though hens supplemented with minerals incorporated diet has resulted higher egg production $(4.42 \pm 2.7$ eggs/week) than the control $(4.23 \pm 3.31 .1$ eggs/week) they were not significantly $(\mathrm{P}>0.05)$ different. The feed conversion rates were $3.35 \pm 0.34$ and $3.24 \pm 0.34$ ( $\mathrm{kg}$ of feed/ $\mathrm{kg}$ of egg) for the treatment and the control.

\section{External Quality of Eggs}

Egg Weight, Egg Width, Length, Shell Thickness and Shape Index: The highest mean egg weight was recorded in the group fed with mineral supplemented diet in the second week. Whereas the egg weights of the control group were significantly $(\mathrm{P}>0.05)$ lower than the mineral supplemented group. However, with the time egg weights of both treatments have shown a reduction (Figure 1). Table 2 indicates the external quality characteristics including width, length, shell thickness and shell strength. Significant differences $(\mathrm{P}<0.05)$ in width between two treatments were recorded in $2^{\text {nd }}$ and $4^{\text {th }}$ week. Values were ranged from 3.5 to $4 \mathrm{~cm}$. The highest 
width was recorded in $3^{\text {rd }}$ week for the control group, but it was not significantly differed with the treatment. Length was significantly different only in $6^{\text {th }}$ week. Shell thickness was only significantly differed in $1^{\text {st }}$ week while shell strength was significantly different in two last weeks $(\mathrm{P}<0.05)$. Mean shell thickness of eggs from two treatments varied from 0.068 to $0.116 \mathrm{~cm}$. Mean shape index of eggs in two treatments are given in the Figure 2. A significant difference between the treatment and the control was indicated in $4^{\text {th }}$ week $(\mathrm{P}<0.05)$. Up to $4^{\text {th }}$ week shape index was higher in hens fed with supplemented diet than the basal diet. But the difference is not significant $(\mathrm{P}>0.05)$. Mean shape index of eggs from two groups was ranged from 63 to $69 \%$.

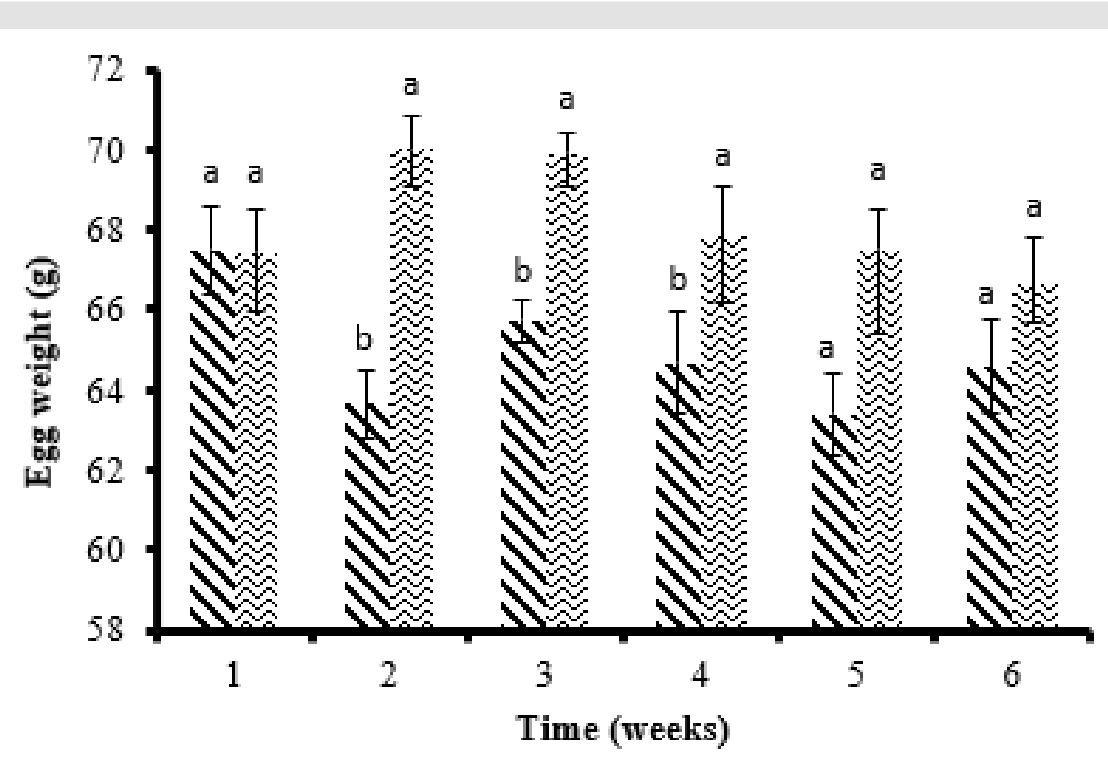

Figure 1: Egg weights (Mean \pm standard error) from $1^{\text {st }}$ to 6 th week Bars with different letters are significantly different for particular week $(\mathrm{P}<0.05),(\mathrm{n}=15) \mathrm{T} 1-$ Basal Diet, T2- Basal Diet $+\mathrm{Na}_{2} \mathrm{SeO}_{3}, \mathrm{FeSO}_{4}, \mathrm{ZnSO}_{4}$.

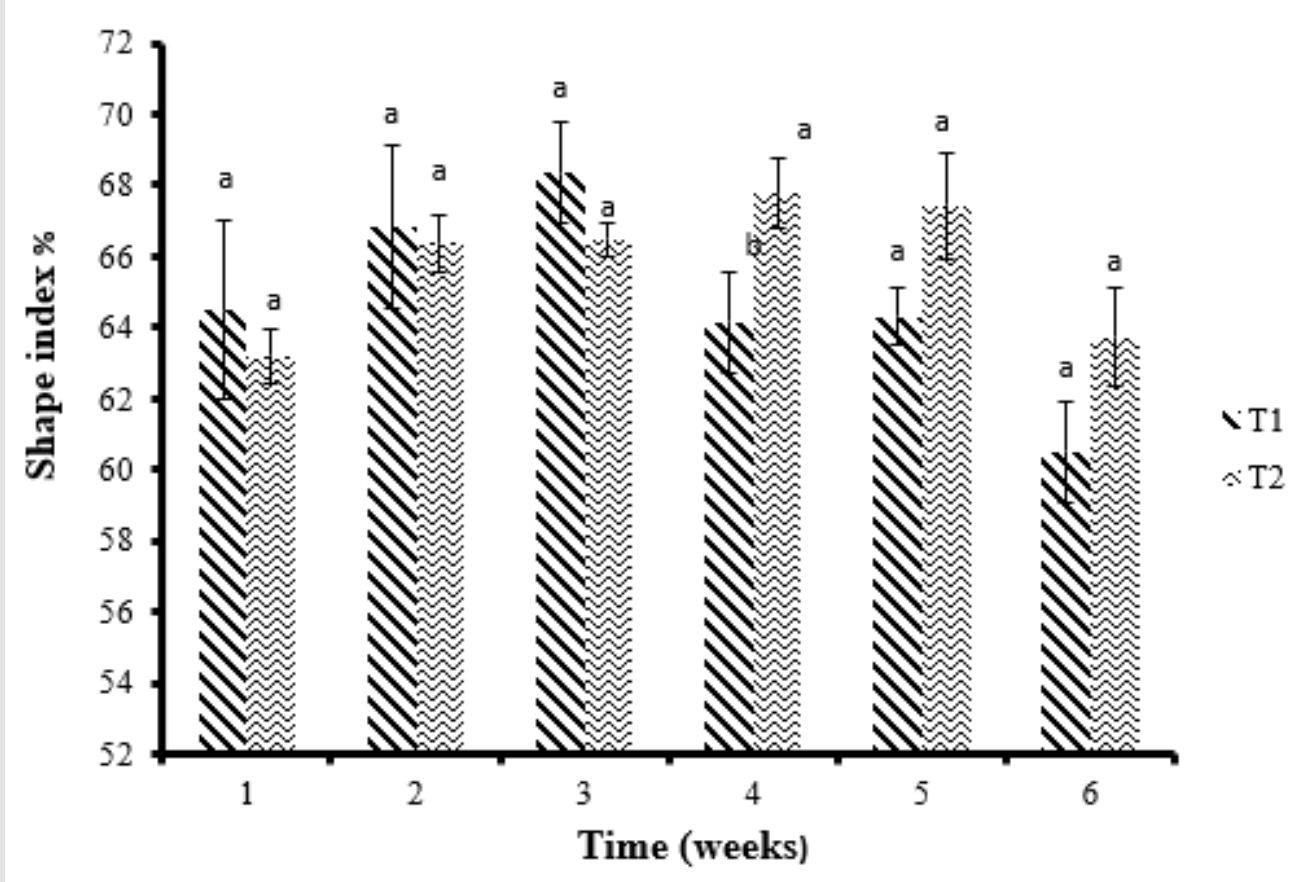

Figure 2: Shape index of eggs (Mean \pm standard error) from $1^{\text {st }}$ to $6^{\text {th }}$ week Bars with different letters are significantly different $(\mathrm{P}<0.05),(\mathrm{n}=15) \mathrm{T} 1-$ Basal Diet T2- Basal Diet $+\mathrm{Na}_{2} \mathrm{SeO}_{3^{\prime}} \mathrm{FeSO}_{4^{\prime}} \mathrm{ZnSO}_{4}$. 


\section{Internal Quality of Eggs}

Haugh Unit, Yolk Index and Yolk Color: Yolk height was significantly different in $4^{\text {th }}$ week and yolk diameter was significantly different in $1^{\text {st }}$ and $4^{\text {th }}$ weeks $(\mathrm{P}<0.05)$. Egg white height recorded a significant difference in $2^{\text {nd }}$ and $3^{\text {rd }}$ weeks $(\mathrm{P}<0.05)$. The average Haugh unit ranged from $28.3 \pm 2.7$ to $72.07 \pm 2.2$ (Figure 3 ). Significant difference of Haugh unit was recorded in $4^{\text {th }}$ week
$(\mathrm{P}<0.05)$. Mean yolk index of two treatments was ranged from 29 to $43 \%$ throughout the experiment period. There was a significant difference $(\mathrm{P}<0.05)$ between eggs from two groups in the $4^{\text {th }}$ week (Figure 4). The highest yolk index was recorded in mineral supplemented group in 2 nd week as $42 \%$. The highest and lowest values for egg yolk color were $5.6 \pm 0.91$ and $4.5 \pm 0.52$ for control group and $6.5 \pm 0.83$ and $4.9 \pm 0.26$ for mineral supplemented group respectively (Figure 5).

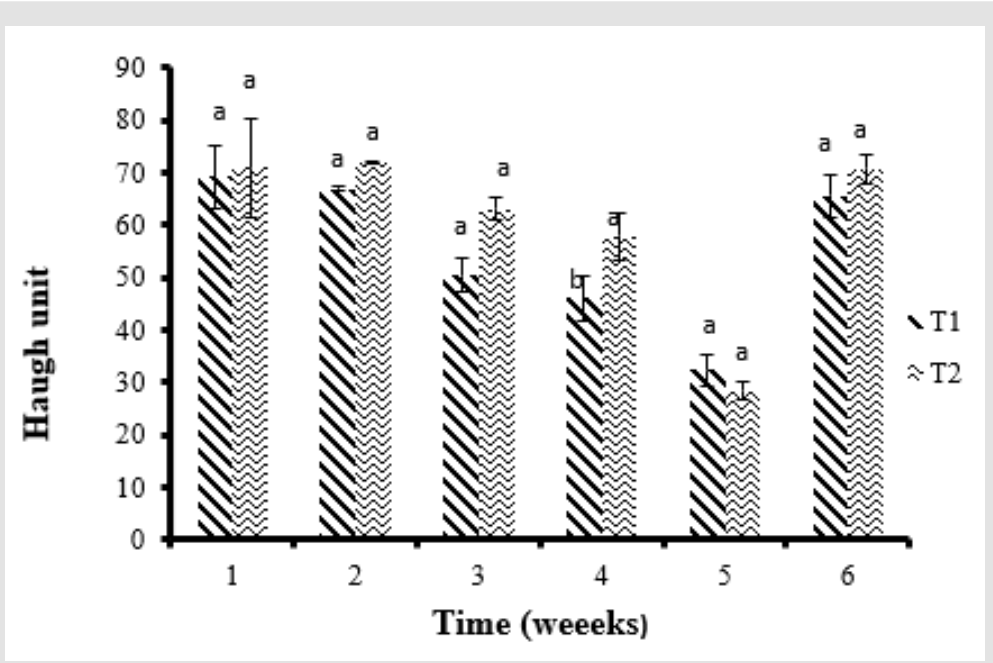

Figure 3: Haugh unit values (Mean \pm standard error) from $1^{\text {st }}$ to $6^{\text {th }}$ week Bars with different letters are significantly different in particular week $(\mathrm{P}<0.05),(\mathrm{n}=15) \mathrm{T} 1-$ Basal Diet T2- Basal Diet $+\mathrm{Na}_{2} \mathrm{SeO}_{3^{\prime}}, \mathrm{FeSO}_{4}, \mathrm{ZnSO}_{4}$.

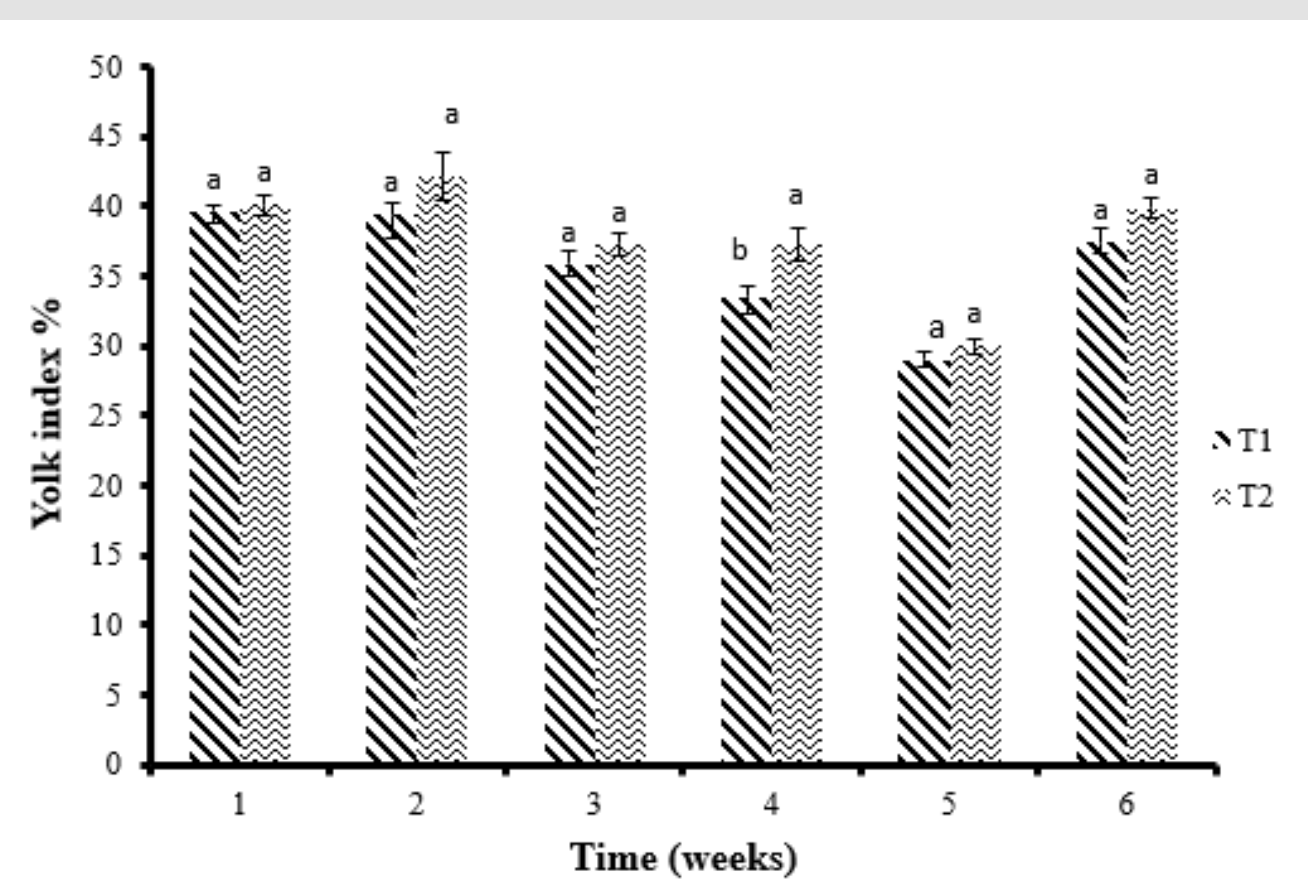

Figure 4: Yolk index of eggs (Mean \pm standard error) from $1^{\text {st }}$ to $6^{\text {th }}$ week Bars with different letters are significantly different $(\mathrm{P}<0.05),(\mathrm{n}=15) \mathrm{T} 1-$ Basal Diet T2- Basal Diet $+\mathrm{Na}_{2} \mathrm{SeO}_{3^{\prime}}, \mathrm{FeSO}_{4^{\prime}} \mathrm{ZnSO}_{4}$. 


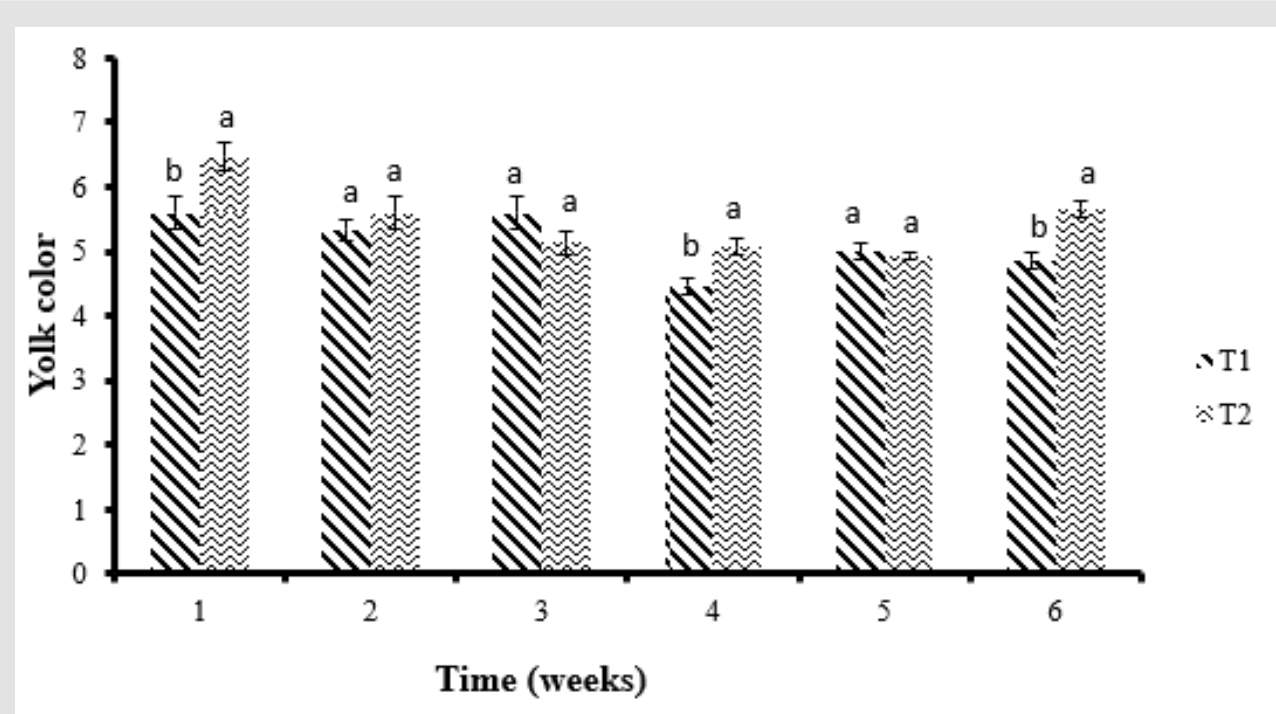

Figure 5: Yolk color of eggs (Mean \pm standard error) from $1^{\text {st }}$ to $6^{\text {th }}$ week Bars with different letters are significantly different $(\mathrm{p}<0.05),(\mathrm{n}=15) \mathrm{T} 1-$ Basal Diet T2- Basal Diet $+\mathrm{Na}_{2} \mathrm{SeO}_{3^{\prime}} \mathrm{FeSO}_{4^{\prime}} \mathrm{ZnSO}_{4}$.

Se, Fe and Zn Concentrations of Egg Yolk and Egg White: Se concentration in egg yolk was not significantly different between two treatments $(\mathrm{P}>0.05)$. But, Se concentration in egg white was significantly $28.6 \%(\mathrm{P}<0.05)$ increased with supplementation of minerals (Table 2). In the case of Fe concentration in egg, the mineral supplemented group showed a significantly higher Fe concentration in egg yolk $(\mathrm{P}<0.05)$ than the control group. Though the egg white Fe concentration in the mineral supplemented group is higher than control group, it was not significantly diffferent $(\mathrm{P}>0.05)$. Fe content in egg yolk has increased by $15.7 \%$ in the group fed with mineral incorporated diet when compared to the control diet and in egg white Fe content has increased by $9.2 \%$ in the mineral supplemented diet than the control diet (Table 2).

Table 2: Se, Fe and Zn concentrations in egg yolk and egg albumen (ppm).

\begin{tabular}{|c|c|c|}
\hline Mineral Concentrations (ppm) & Basal diet (T1) & Basal diet $+\mathrm{Na}_{2} \mathrm{SeO}_{3}, \mathrm{FeSO}_{4}$ and $\mathrm{ZnSO}_{4}$ (T2) \\
\hline \multicolumn{3}{|c|}{ Egg yolk } \\
\hline $\mathrm{Se}$ & $0.34 \pm 0.01^{\mathrm{a}}$ & $0.35 \pm 0.01^{\mathrm{a}}$ \\
\hline $\mathrm{Fe}$ & $56.01 \pm 2.80^{\mathrm{b}}$ & $64.78 \pm 2.20^{\mathrm{a}}$ \\
\hline $\mathrm{Zn}$ & $33.81 \pm 2.60^{\mathrm{a}}$ & $34.30 \pm 3.40^{\mathrm{a}}$ \\
\hline \multicolumn{3}{|c|}{ Egg white } \\
\hline Se & $0.21 \pm 0.01^{\mathrm{b}}$ & $0.27 \pm 0.01^{\mathrm{a}}$ \\
\hline $\mathrm{Fe}$ & $39.05 \pm 2.70^{\mathrm{a}}$ & $39.66 \pm 2.20^{\mathrm{a}}$ \\
\hline $\mathrm{Zn}$ & $4.28 \pm 0.48^{\mathrm{b}}$ & $6.46 \pm 0.53^{a}$ \\
\hline
\end{tabular}

Note: Data expressed as mean \pm standard error $(n=6, P<0.05)$.

Sensory Evaluation: The sensory quality evaluation results of hard-boiled eggs of control and mineral supplemented hens are presented in the Figure 6. Results indicated that the eggs from mineral supplemented group had a significantly higher color difference than control group $(\mathrm{P}<0.05)$. In addition to that, other sensory attributes including appearance, aroma, flavor and overall acceptability were not significantly different $(\mathrm{P}>0.05)$. 


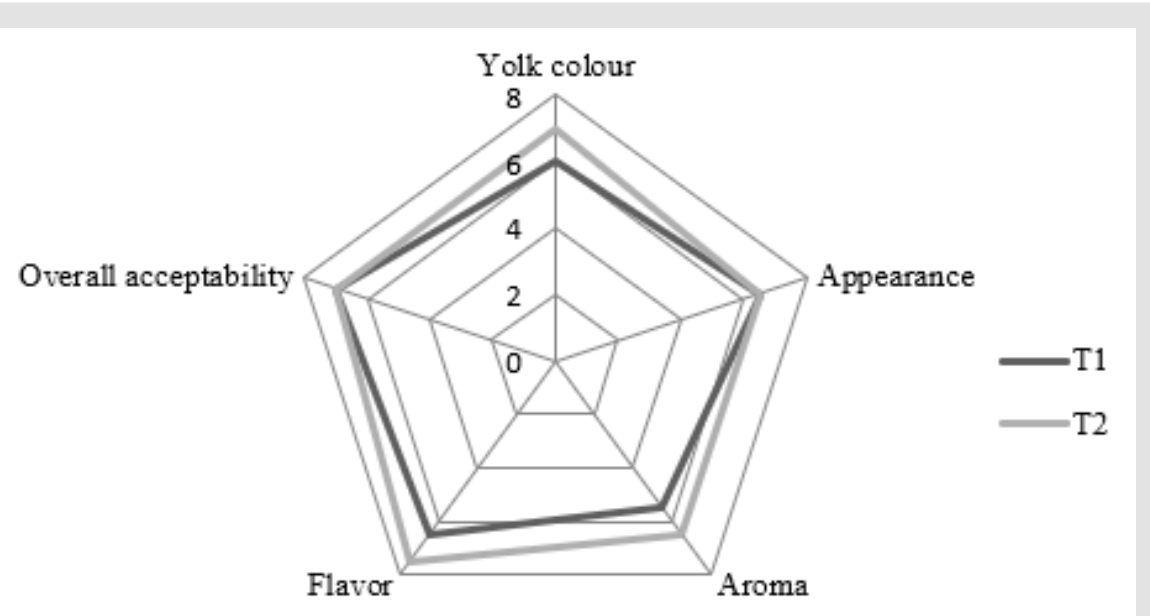

Figure 5: Variation of sensory attributes in two treatments T1- Basal Diet T2- Basal Diet $+\mathrm{Na}_{2} \mathrm{SeO}_{3^{\prime}} \mathrm{FeSO}_{4^{\prime}} \mathrm{ZnSO}_{4}$.

\section{Discussion}

\section{Productive Performances of Laying Hens}

The feed intake, egg production and feed conversion rates were not significantly difference between the two groups of the present study. Skrivan, et al. [20] have also reported similar productive performance results when supplementing Sodium selenite, Seenriched yeast and Se-enriched chlorella to ISA Brown laying hens at 24 weeks of age. The values for feed intake/hen/day have ranged from 112-118 g. The current supplementation level might have not affected the organoleptic properties of the diet. Hence, it did not affect the feed intake negatively. Further it is known that the management and the environmental factors mostly affect the feed intake. Contradictory to the current findings Ramadan [26], observed significant $(\mathrm{P}<0.05)$ decreased in mean feed intake of Mandarah laying hens when the diets supplemented with $\mathrm{Fe}$ levels of 100 or $200 \mathrm{mg} \mathrm{Fe} / \mathrm{kg}$ of diet. The results of present study with respect to the egg production are clearly in agreement with the studies conducted by Skrivan, et al. [20,21]. They have used organic and inorganic sources of Se as the same level as the current study. Feed conversion rate/kg of eggs also were not significantly different. Bahakaim, et al. [22], have found that the improvement in feed conversion, but was not significant at the level of $150 \mathrm{mg}$ zinc/kg compared to the control diet. The feed conversion ratio of poultry is heritable and also can be affected by gastrointestinal tract traits De Verdal [27].

\section{External Quality of Eggs}

Egg Weight: The current study showed significant increase of egg weights compared to the control (Figure 1). Similarly Ramadan, et al. [26] have found a remarkable increase of egg weights when layers fed with supplemental iron at the level of $100 \mathrm{mg} / \mathrm{kg}$ of diet in combination with $\mathrm{Zn}$. The increment was $20 \%$ as compared to the control diet. Mean egg weight reported by Skrivan, et al. [20] was in comparable with the current study, for the hens fed with organic and inorganic selenium sources supplemented diet. Bahakaim, et al. [22] have observed significant difference in egg weight by supplementing zinc sources to the laying hen's diet. Saldanha [28] reported that this could be related to the positive effect of organic selenium on the absorption and/or protection of fat-soluble vitamins. Further, the combination of the trace minerals used in this study might have facilitated better utilization of nutrients resulting higher egg weights than the control even though, the feed conversion ratio was not significantly different among the two groups.

Egg Width, Length, Shell Thickness and Shape Index: Arpasova, et al. [29] have found similar results compared to the current study with regard to the egg width and length when supplementing organic and inorganic sources to the laying hens. Pavlović, et al. 2010 reported that supplementation of Se up to 0.8 $\mathrm{mg} / \mathrm{kg}$ does not affect the eggshell quality characteristics. Effect of mineral supplementation on eggshell strength is contrary in the study compared to Richter, et al. (2006) and they have observed increased in eggshell strength by supplementing both organic and inorganic forms of Se.

Haugh Unit, Yolk Index and Yolk Color: Skrivan, et al. [20] reported that sodium selenite and Se-yeast were not effective to increase the Haugh unit. Egg albumin height and Haugh unit values decrease with the storage time and it happens quickly at high temperatures. Bertchini, et al. [30] have reported that there was no significant effect of Fe supplemented diet at the level of 20, 40, 60 and $80 \mathrm{ppm} \mathrm{Fe} / \mathrm{kg}$ on egg quality except for Haugh unit. Bahakaim, et al. [22] have reported that supplementation of $\mathrm{Zn}$ in different levels to the laying hens has significant effect on albumen index, Haugh unit and shell thicknesses with an exception of the results reflected by the current study. The preferable results for egg quality were recorded with supplementation of $50 \mathrm{mg} \mathrm{Zn/kg}$ and $100 \mathrm{mg}$ of $\mathrm{Zn} / \mathrm{kg}$ with the basal diet. Further supplementation of organic minerals ( $\mathrm{Ca}, \mathrm{P}, \mathrm{Cu}, \mathrm{Fe}, \mathrm{Mn}$, and $\mathrm{Zn}$ ) up to $0.3 \mathrm{~g} / \mathrm{kg}$ of feed has not 
affected egg quality parameters Saldanha, et al. (2010). In the current study, significant differences in yolk color were recorded in the first, fourth and sixth weeks. Chen, et al. [31] reported that rations with different Fe formulations had a significant effect on egg yolk color. The current combination of minerals might have an effect on pigment transportation and/or accumulation of egg yolk. However, it might not have affected to the synthesis of egg white proteins.

Se, Fe and Zn Concentrations of Egg Yolk and Egg White: After 14 days of supplementing of both organic and inorganic sources of Se including Sodium selenite, Se-yeast and Se-Chlorella to ISA brown laying hens, Skrivan, et al. [20] have found that Se concentration in egg white is significantly higher than egg yolk. The level of Se supplementation was at the same concentration as the present study. Nonetheless Cantor [32] has shown that Se can be effectively deposited in egg yolk than in egg white. The results from various experiments are contradictory, Se supplemental level and source of Se most obviously affect to the Se concentrations in egg components. Due to higher bioavailability of Se in organic sources than inorganic sources, supplementing of organic sources of Se is considered as the most effective way to enrich the egg with Se Payne [20,33,34].

Ramadan, et al. [26], have conducted a research to investigate the effect of using different levels of Fe with $\mathrm{Zn}$ and $\mathrm{Cu}$ in layer's diet on egg iron enrichment and results of the study have shown that with increasing Fe level in the diet from 0.0 to 100 and $200 \mathrm{mg} / \mathrm{kg}$ have significantly $(\mathrm{P}<0.01)$ increased the egg iron contents by 33.97 and $57.89 \%$ respectively than the control group. Skrivan, et al. [23] have observed that the $\mathrm{FeSO}_{4}$ incorporated diet has increased the $\mathrm{Fe}$ concentration in egg yolk and white by 6.3 and $2.2 \%$, respectively. Moreover, the same concentration of Fe in the diet was used in the present study [35]. Thus supplementation of iron in combination of Se and $\mathrm{Zn}$ is effective in enriching eggs with those minerals under the tropical climatic conditions.

Zinc concentration in the egg yolk for the control diet and supplemented diets were $33.81 \pm 2.6$ and $34.30 \pm 3.4 \mathrm{mg} / \mathrm{kg}$ respectively. Though, it was higher in treatment group than the control, the difference was not significant $(\mathrm{P}>0.05)$. Interestingly the egg white $\mathrm{Zn}$ concentration was significantly higher when hens supplemented with mineral incorporated diet than basal $\operatorname{diet}(\mathrm{P}<0.05)$. The current study revealed that supplementing of $\mathrm{ZnSO}_{4}(150 \mathrm{mg} / \mathrm{kg}$ with the basal diet was effective to increase the $\mathrm{Zn}$ concentration in the egg white by $50.9 \%$ (Table 2). Thus Fe supplementation is highly effective in enriching the egg yolk whereas Se and Zn supplementation is more effective in enriching egg white than the yolk when $\mathrm{Fe}$, Se and $\mathrm{Zn}$ are supplemented in combination [36-38].

Sensory Evaluation: The present multimineral combination has increased the yolk colour. Similar observation has been found be Chen et al, in 2018 with supplementation of Fe. With respect to the acceptability of hard-boiled egg samples, it can be expressed that mineral supplementation has positively affected to the sensory attributes of eggs. The literature on sensory evaluation results of enriched eggs is limited [39]. Though Buckiunien et al., have conducted a sensory evaluation, but they have not measured yolk color in boiled eggs. The present study indicated that the Se, Fe and $\mathrm{Zn}$ supplementation at the given levels has a positive effect on egg yolk color.

\section{Conclusion}

Mineral supplemented diet with inorganic sources of Sodium selenite, Zinc sulphate and Ferrous sulphate does not alter the feed intake, egg production and feed conversion rate in layers under tropical conditions. Inorganic forms of Se, Fe and $\mathrm{Zn}$ favorably affect to increase the total egg weight. The multi mineral combination of $\mathrm{Se}, \mathrm{Fe}$ and $\mathrm{Zn}$ sources on egg internal and external quality shows positive influences. With respect to three supplemented mineral sources, Sodium selenite and Zinc sulphate are effective in enriching the egg white with Se and Zn, by $28.6 \%$ and $50.9 \%$ respectively. While Ferrous sulphate fortifies the egg yolk by $15.7 \%$ than the basal diet. Mineral supplemented diet with $\mathrm{Na}_{2} \mathrm{SeO}_{3}(0.3 \mathrm{mg} / \mathrm{kg})$, $\mathrm{FeSO}_{4}(120 \mathrm{mg} / \mathrm{kg})$ and $\mathrm{ZnSO}_{4}(150 \mathrm{mg} / \mathrm{kg})$ can be recommended to fortification of eggs with $\mathrm{Se}, \mathrm{Fe}$ and $\mathrm{Zn}$ successfully and, it results positive improvements in egg quality especially the yolk color. Se, Fe and $\mathrm{Zn}$ supplemented diet increases the consumer preferences of eggs by increasing egg yolk color.

\section{References}

1. (2006) Food and Agriculture Organization/World Health Organization (FA)/WHO). Guidelines on food fortification with micronutrients, World Health Organization and Food and Agriculture Organization of the United Nations, Geneva, Switzerland.

2. (2004) Food and Agriculture Organization/World Health Organization (FAO/WHO). Expert consultation on human vitamin and mineral requirements. ( $2^{\text {nd }}$ Edn.)., Food and Agriculture Organization of the United Nation and World Health Organization, Bangkok, Thailand.

3. Tinggi U (2008) Selenium: its role as antioxidant in human health. Environmental Health and Preventive Medicine 13(2): 102-108.

4. Oguntibeju 0, Esterhuyse JS, Truter EJ (2009) Selenium: its potential role in male infertility. Pakistan Journal of Medical Sciences 5(2): 332-337.

5. Randjelovic P, Veljkovic S, Stojiljkovic N, Velickovic L, Sokolovic D, et al. (2012) Protective effect of selenium on gentamicin-induced oxidative stress and nephrotoxicity in rats. Drug Chemical Toxicology 35(2): 141148.

6. Wiesen P, Overmeire LV, Delanaye P, Dubois B, Preiser JC (2011) Nutrition disorders during acute renal failure and renal replacement therapy. Journal of Parenteral Enteral Nutrition 35(2): 217-222.

7. (2013) World Health Organization (WHO) Investigation and Evaluation of Chronic Kidney Disease of Uncertain Aetiology in Sri Lanka. Final Report, Geneva, Thailand.

8. Fisinin VI, Papazyan TT, Surai PF (2008) Producing specialist poultry products to meet human nutrition requirements: Selenium enriched eggs. World's Poultry Science Journal 64(1): 85-98. 
9. Dallman PR (1986) Biochemical basis for the manifestations of iron deficiency. Annual Review of Nutrition 6: 13-40.

10. Andrews NC (1999) Disorders of iron metabolism. New England Journal of Medicine 341(26): 1986-1995.

11. Haas JD, Brownlie T (2001) Iron deficiency and reduced work capacity: A critical review of the research to determine a causal relationship. Journal of Nutrition 131: 676S-688S.

12. Paul BT, Manz DH, Torti FM, Torti SV (2017) Mitochondria and Iron: Current Questions. Expert Review of Hematology 10(1): 65-79.

13. Maret W (2013) Zinc Biochemistry: From a Single Zinc Enzyme to a Key Element of Life. Advances in Nutrition 4(1): 82-91.

14. Prasad AS (2003) Zinc deficiency: Has been known of for 40 years but ignored by global health organizations. British Medical Journal 326(7386): 409-410.

15. Hambidge KM, Krebs NF (2007) Zinc deficiency: a special challenge. Journal of Nutrition 137(4): 1101-1105.

16. Meydani SN, Barnett JB, Dallal GE (2007) Serum zinc and pneumonia in nursing home elderly. American Journal of Clinical Nutrition 86(4): 1167-1173.

17. Edens FW (2002) Practical applications for selenomethionine: broiler breeder reproduction. Proceedings of the $18^{\text {th }}$ Alltech's Annual Symposium, Nottingham University Press, Nottingham, UK, p. 29-42.

18. Khan MT, Mahmud A, Zahoor I, Javed K (2017) Organic and inorganic selenium in Aseel chicken diets: Effect on hatching traits. Poultry Science 96(5): 1466-1472.

19. Rajapakse S, Shivanthan MC, Selvaraja M (2016) Chronic kidney disease of unknown etiology in Sri Lanka. International Journal of Occupational and Environmental Health 22(3): 259-264.

20. Skrivan M, Simane J, Dlouhal G, Doucha D (2006) Effect of dietary sodium selenite, Se-enriched yeast and Se-enriched Chlorella on egg Se concentration, physical parameters of eggs and laying hen production. Czech Journal of Animal Science 51(4): 163-167.

21. Chinrasri O, Chantiratikul P, Thosaikham W, Atiwetin P, Chumpawadee S, et al. (2009) Effect of Selenium-enriched bean sprout and other Selenium sources on productivity and Selenium concentration in eggs of laying hens. Asian-Australian Journal of Animal Science 22(12): 16611666.

22. Bahakaim ASA, Magied HAA, Osman SMH, Omar AS, AbdelMalak NY, et al. (2014) Effect of using different levels and sources of zinc in layer's diets on egg zinc enrichment. Egypt Journal of Poultry Science 34(1): 39 -56.

23. Skrivan M, Skrivanova V, Marounek M (2005) Effects of dietary Zinc Iron, and Copper in layer feed on distribution of these elements in eggs, liver, excreta, soil, and herbage. Poultry Science 84(10): 1570-1575.

24. Reddy PM, Reddy VR, Reddy CV, Rap SP (1979) Egg weight, shape index and hatchability in khaki Campbell duck egg. Indian Journal of Poultry Science 14(1): 26-31.
25. Haugh RR (1937) The Haugh unit for measuring egg quality. US Egg Poultry Management 43: 552-555, 572-573.

26. Ramadan NA, Omar AS, Bahakaim ASA, Osman SMH (2010) Effect of using different levels of Iron with Zinc and Copper in layer's diet on egg iron enrichment. International Journal of Poultry Science 9(9): 842-850.

27. De Verdal, H, Narcy A, Bastianelli D, Chapuis H, Meme N, et al. (2011) Improving the efficiency of feed utilization in poultry by selection. 1. Genetic parameters of anatomy of the gastro-intestinal tract and digestive efficiency. BMC Genetics 12: 59.

28. Saldanha ESPB, Garcia EA, Pizzolante CC, Faittarone ABG, Sechinato A da, et al. (2009) Effect of organic mineral supplementation on the egg quality of semi-heavy layers in their second cycle of lay. Brazilian Journal of Poultry Science 11(4): 215-222.

29. Arpasoval H, Mellen M, Kacanioval M, Hascikl P, Petrovic V, et al. (2006) Effects of dietary supplementation of sodium selenite and selenized yeast on selected qualitative parameters of laying hens eggs. Slovak Journal of Animal Science 42(1): 27-33.

30. Bertchini AG, Fassiani A, Fialho ET, Spadoni A (2000) Iron supplementation for commercial laying hens in second cycle of production. Revista Brasileira de Ciencia Avicola 2(3): 267-272.

31. Chen YJ, Cho JH, Yoo JS, Wang Y, Huang Y, et al. (2008) Evaluation of $\delta$ aminolevulinic acid on serum iron status, blood characteristics, egg performance and quality in laying hens. Asian-Australasian Journal of Animal Science 21(9): 1355-1360.

32. Cantor AH (1997) The role of selenium in poultry nutrition. In: TP Lyons, KA Jacques (Eds.)., Biotechnology in the Feed Industry. Proceedings of Alltech $13^{\text {th }}$ Annual Symposium, 1999, Notingham University Press, Nottingham, UK, pp. 155-164.

33. Payne RL, Lavergne TK, Southern LL (2005) Effect of inorganic versus organic selenium on hen production and egg selenium concentration. Poultry Science 84(2): 232-237.

34. Chantiratikul A, Chinrasri 0, Chantiratikul P (2008) Effect of sodium selenite and zinc-L-selenomethionine on performance and selenium concentrations in eggs of laying hens. Asian-Australian Journal of Animal Science 21(7): 1048-1052.

35. Bleau G, Lemarbre J, Faucher G, Roberts KD, Chapdelaine A (1984) Semen selenium and human fertility. Fertility and Sterility 42(6): 890894.

36. Combs GF, Combs SB (1986) The role of Selenium in nutrition, Academic press, New York, USA.

37. Kok F, Hofman A, Witterman JCM (1989) Decreased Se levels in acute myocardial infarction. Journal of the American Medical Association 261(8): 1161-1164.

38. Latshaw JD, Osman M (1974) A selenium and vitamin E responsive condition in the laying hen. Poultry Science 53(5): 1704-1708.

39. (1994) National Research Council (NRC). Nutrient Requirements of Poultry. ( $9^{\text {th }}$ Edn.)., National Academy Press. Washington, DC, USA. 
ISSN: 2574-1241

DOI: 10.26717/BJSTR.2021.35.005683

Himali SMC. Biomed J Sci \& Tech Res

(c) (P) This work is licensed under Creative BY Commons Attribution 4.0 License

Submission Link: https://biomedres.us/submit-manuscript.php

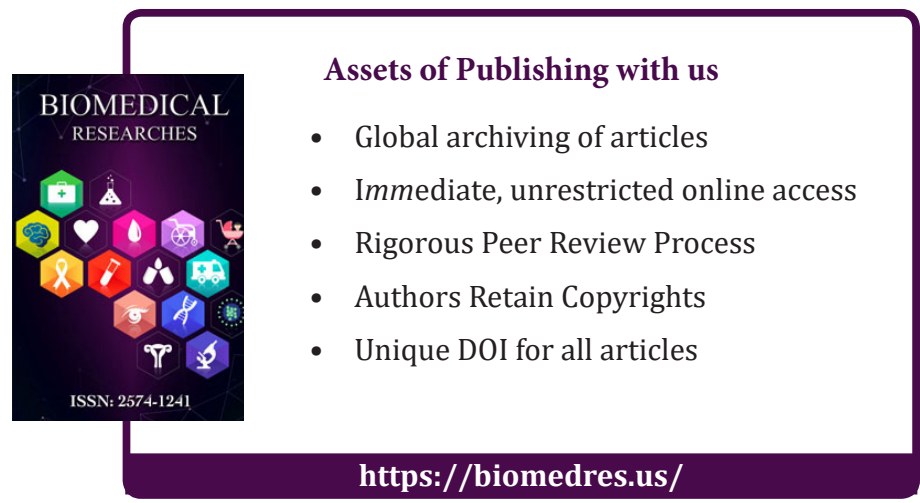

